\title{
Bioactive properties of marine fish skin gelatin hydrolysate: Optimisation using response surface methodology
}

\author{
VAHIDEH MOKHTARNEZHAD, ALI TAHERI AND ALI MOTAMEDZADEGAN* \\ Chabahar Maritime University, P. O. Box. 99717- 56499, Chabahar, Sistan and Baluchestan Province, Iran \\ *Sari Agricultural Sciences and Natural Resources University, Mazandaran Province, Sari \\ Km 9 Farah Abad Road - 48181 68984, Iran \\ e-mail: taherienator@gmail.com
}

\begin{abstract}
Adverse effects of free radicals on food oxidation have increasingly been investigated recently. Antioxidants have many health benefits as bioactive materials and are widely used in food industries. The effects of three main factors namely, time $(60,150,240 \mathrm{~min})$, temperature $\left(40,52,65^{\circ} \mathrm{C}\right)$ and enzyme to substrate ratio $(1,3,5 \%)$ on fish gelatin hydrolysation were studied in order to obtain optimum antioxidative properties. Response surface methodology (RSM) was used to fit the model and ridge analysis to optimise the selected factors. The percentage of $\mathrm{Fe}^{2+}$ chelating activity was considered as the response. $\mathrm{R}^{2}$ confirmed that the model fitted well with the experimental data $\left(\mathrm{R}^{2}=0.97\right)$. Optimal conditions were found to be at a temperature of $56.55^{\circ} \mathrm{C}$, enzyme to substrate ratio of $4.93 \%$ and time of $149.23 \mathrm{~min}$. Under optimum conditions, metal chelating activity achieved was $82.33 \%$. The results showed that fish skin gelatin hydrolysate had good antioxidative properties and could be a candidate for in vivo studies for industrial applications.
\end{abstract}

Keywords: Antioxidant, Fish gelatin hydrolysate, Metal chelating activity, Response surface methodology

\section{Introduction}

Gelatin is a water soluble protein produced by hydrolysis of animal collagen (Gomez-Guillen et al., 2011) and because of its special functions and properties, is widely used in various industries (Karim and Bhat, 2009). Raw materials used for the extraction of collagen and gelatin are skin, bone, tendons and cartilage of animals (Gómez-Guillen et al., 2011). Usually, gelatin is made from skin and bones of pigs and cows. Pigskin gelatin is not accepted in Islam and Judaism and cow's gelatin is acceptable if produced according to religious requirements (Badii and Howell, 2006). Due to the outbreak of bovine spongiform encephalopathy (BSE) and foot and mouth disease in cows (FMD) as along with the prohibition of collagen produced from the skin and bones of pigs due to religious reasons, it is essential to introduce alternative sources (Duan et al., 2011).

Lipid oxidation during processing and storage of food products harms quality by changing their appearance, flavour, odour, shelf-life and nutritive value. This effect leads to decreased consumer acceptance (Aewsiri et al., 2010; Sarmadi and Ismail, 2010). Also, oxidised foods cause serious illness (Aleman et al., 2011a). Furthermore, uncontrolled generation of free radicals attacks the membrane proteins, fats and DNA, which leads to the development of many chronic diseases, including cardiovascular diseases, neurological disorders, diabetes, inflammatory diseases, hypertension, aging, stomach ulcers and certain types of cancer (Mendis et al., 2005b; Phanturat et al., 2010). Antioxidants can protect the body from free radicals and lipid peroxidation and delay its complications (Najafian and Babji, 2012).

Synthetic antioxidants like BHT (butylated hydroxytoluene), BHA (butylated hydroxyl anisole), or $\mathrm{N}$ - propyl gallate have shown intense antioxidant activity. But their use is significantly reduced because of the potential health risks. Hence, identification of antioxidants from natural sources became a topic of interest (Gimenez et al., 2009). In the past decade, several studies have focused on the antioxidant properties of marine proteins and peptides. According to them, protein hydrolysis of aquatics has shown an excellent antioxidant property, among them following studies are worth mentioning: scallops (Patinopecten yessoensi) and abalone (Haliotis discushannai Ino) muscle protein hydrolysates (Zhou et al., 2012), Pacific cod (Gadus macrocephalus) gelatin hydrolysate (Ngo et al., 2011), tilapia (Oreochromis niloticus) skin gelatin hydrolysates (Zhang et al., 2012) and Alaska pollock skin gelatin hydrolysates (Kim et al., 2001).

Changes in hydrolysis conditions, such as temperature, time and enzyme to substrate ratio, lead 
to changes in properties of the final product. Therefore, achieving best reaction conditions is essential for ensuring the highest antioxidant properties. Optimisation by modern experimental designs is a way to achieve the best results with reduced analysis costs (Yang et al., 2009).

Marine catfish Netuma thalassina (Ruppell 1837) (=Arius thalassinus) caught heavily in trawls in the Chabahar Bay (Iran) is not edible in Iran and is mostly used by fishmeal industries. However, the skin of this fish species has the potential for extraction of gelatin with antioxidant properties. Therefore, this study was conducted to optimise marine catfish skin gelatin hydrolysate production by response surface methodology (RSM) and the antioxidant activity was used as a response.

\section{Materials and methods}

\section{Fish preparation}

Fresh fish catch of $N$. thalassina collected from the Chabahar Fishing Port, Iran was used for this study. Samples (stored in ice during transportation) were moved to the Biotechnology Laboratory of the Chabahar Maritime University and stored at $-20^{\circ} \mathrm{C}$ until further use. All chemicals such as enzymes, citric acid, sulfuric acid and sodium hydroxide were purchased from Sigma-Aldrich (Iranian branch, Tehran).

\section{Fish gelatin production}

Fish samples were defrosted at refrigerator temperature. Skin tissue was removed and cut into small pieces $(1 \times 1 \mathrm{~cm})$, then washed under running tap water to remove superfluous material. Gelatin was extracted from the skin, according to the method described by Koli et al. (2012), with slight modifications. Briefly, the skin samples were immersed in $0.2 \%(\mathrm{w} / \mathrm{v})$ sodium hydroxide, sulfuric acid $0.2 \%(\mathrm{w} / \mathrm{v})$ and citric acid $1.0 \%(\mathrm{w} / \mathrm{v})$, respectively. In all treatments, acid and base solution was replaced every $40 \mathrm{~min}$ with a total time of $2 \mathrm{~h}$ for each treatment. After each treatment, skin samples were washed with distilled water and normal $\mathrm{pH}$ of 7 was obtained before conduction to the new solution. The ratio of skin to acid or base solution was 1: $6(\mathrm{w} / \mathrm{v})$ for each treatment. The skin tissues were then treated in $76 \%$ ethyl alcohol to remove fat. At all stages, Shaker Incubator (Fan Azma Gostar, Model: $\mathrm{K}_{\mathrm{m}}$ 55, Iran) with continuous gentle stirring was used. The skin samples were then washed with distilled water.

The gelatin extraction was performed in 3 volumes of distilled water at $45^{\circ} \mathrm{C}$ for $12 \mathrm{~h}$ with continuous stirring in a shaker incubator. The mixtures were then filtered using a Buchner funnel with Whatman filter paper (no. 1). Then, the filtrate was freeze-dried (Jalteb, Iran) for $20 \mathrm{~h}$. Dried gelatin was stored at $20^{\circ} \mathrm{C}$ until use.

\section{Hydrolysis of skin gelatin}

The skin gelatin was hydrolysed with the enzyme Protamex under controlled conditions, as shown in Table 1. The enzyme with different ratios (Table 1) was added to $10 \mathrm{ml}$ gelatin $(1.0 \%, \mathrm{w} / \mathrm{v})$, and the mixture was incubated with stirring at desired temperature and times. Subsequently, the enzyme was deactivated by heating at $90^{\circ} \mathrm{C}$ for $10 \mathrm{~min}$ and then centrifuged at $3000 \mathrm{rpm}$ for 15 min (Centurion Scientific, Model: K241R, England). The supernatant was collected as gelatin hydrolysate and freeze-dried (Alemán et al., 2011b).

\section{Antioxidant properties}

The $\mathrm{Fe}^{2+}$ chelating activity was estimated by the method of Intarasirisawat et al. (2002) with some modification. $\mathrm{FeCl}_{2}(0.1 \mathrm{ml}, 2 \mathrm{mM})$ was mixed with the diluted test sample $(3.7 \mathrm{ml})$. Then, ferrozine solution $(0.2 \mathrm{ml}, 5 \mathrm{mM})$ was added to the mixture. The absorbance was measured at $562 \mathrm{~nm}$ using a spectrophotometer (Unicon spectrophotometer, Model: S2100 SUV, USA) after $10 \mathrm{~min}$ at room temperature. Distilled water instead of the sample and EDTA were used as blank and control, respectively.

The chelating activity was calculated according to the following formula:

$\mathrm{Fe}^{2+}$ chelating activity $(\%)=[(\mathrm{B}-\mathrm{A}) / \mathrm{B}] \times 100$

where $\mathrm{A}$ is the absorbance of the sample and $\mathrm{B}$ is the absorbance of blank.

\section{Mathematical model}

Response surface methodology (RSM) was used to optimise enzymatic hydrolysis conditions (Guerard et al., 2007; Ren et al., 2008). The effect of independent variables, including temperature $\left({ }^{\circ} \mathrm{C}, \mathrm{A}\right)$, time (min, B) and enzyme to substrate ratio $(\%, \mathrm{C})$, was evaluated at 3 levels (Table 2). Percentage of chelating activity was selected as the dependent variable. The central composite design consisted of 20 treatments including eight factorial points, six axial points and six replicates around the central point (to estimate the experimental error), for the optimisation process (Table 1). Three-dimensional plots were used to study the trends. Design Expert 7.00 software was used for data analysis.

Based on the experimental data, multiple regression modeling in the form of a second-order polynomial was used as follows:

$Y=\beta_{0}+\beta_{I} X_{1}+\beta_{2} X_{2}+\beta_{3} X_{3}+\beta_{1 I} X_{1}^{2}+\beta_{22} X_{2}^{2}+\beta_{33} X_{3}^{2}+\beta_{12} X_{I} X_{2}+\beta_{13} X_{T} X_{3}$

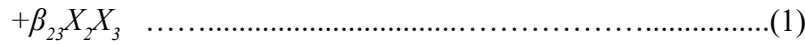

where $Y$ is the estimated response, $\beta_{0}$ the constantcoefficient, $\beta_{1}, \beta_{2}, \beta_{3}$ are linear coefficients, $\beta_{11}, \beta_{22}, \beta_{33}$ the quadratic coefficients and $\beta_{12}, \beta_{13}, \beta_{23}$ the interaction coefficients. 
Table 1. Experimental design for optimising the hydrolysis condition of sea catfish ( $N$. thalassina) skin gelatin

\begin{tabular}{lll}
\hline Temperature $\left({ }^{\circ} \mathrm{C}\right)$ & Time $(\mathrm{min})$ & $\begin{array}{l}\text { Enzyme-substrate } \\
\text { ratio }(\mathrm{e} / \mathrm{s}, \%)\end{array}$ \\
\hline 40 & 240 & 1 \\
65 & 150 & 3 \\
40 & 60 & 5 \\
52.5 & 150 & 3 \\
52.5 & 240 & 3 \\
52.5 & 150 & 3 \\
65 & 60 & 1 \\
40 & 240 & 5 \\
52.5 & 150 & 5 \\
52.5 & 150 & 3 \\
65 & 240 & 5 \\
52.5 & 150 & 1 \\
52.5 & 150 & 3 \\
40 & 150 & 3 \\
40 & 60 & 1 \\
52.5 & 150 & 3 \\
52.5 & 150 & 3 \\
65 & 60 & 5 \\
52.5 & 60 & 3 \\
65 & 240 & 1 \\
\hline
\end{tabular}

Table 2. Independent variables and their level for optimising the hydrolysis condition of sea catfish ( $N$. thalassina) skin gelatin

\begin{tabular}{lllll}
\hline Independent variables & Symbol & \multicolumn{3}{c}{ Code value levels } \\
\hline & & $1+$ & 0 & $1-$ \\
\cline { 3 - 5 } Temp $\left({ }^{\circ} \mathrm{C}\right)$ & $\mathrm{A}$ & 65 & 52 & 40 \\
Time $(\min )$ & $\mathrm{B}$ & 240 & 150 & 60 \\
e/s $(\%)$ & $\mathrm{C}$ & 5 & 3 & 1
\end{tabular}

\section{Results and discussion}

In this study, hydrolysis conditions were optimised by RSM model to produce skin gelatin peptides from $N$. thalassina with high antioxidant properties. Analysis of variance for the linear, the quadratic and the interaction of the three variables (A, B and C) on the response values (Y) are shown in Table 3. Each of the linear coefficients of explanatory variables was significant at $5 \%$ level; temperature $(\mathrm{p}$ value $<0.0001)$, time $(\mathrm{p}$ value $=0.0008)$ and enzyme to substrate ratio ( $p$ value $<0.0001$ ). Among the quadratic coefficients, time and enzyme to substrate ratio showed significance at $5 \%$ level.

Transition metals such as $\mathrm{Fe}, \mathrm{Cu}$, and $\mathrm{Co}$ in foods can accelerate autoxidation and break hydrolytic to volatile compounds (Klompong et al., 2007). They also can catalyse the reactive oxygen species generation, such as hydroxyl radical $\left(\mathrm{OH}^{\circ}\right)$ and superoxide anion $\left(\mathrm{O}_{2}{ }^{-}\right)$ and then activate the lipid peroxidation chain reaction.
Therefore, the chelation of metal ions by antioxidants reduces the oxidation reaction (Farvin et al., 2014). It is believed that acidic or basic amino acids through carboxyl and amino groups in their side chains have an essential role in the chelation of metal ions (Rajapakse et al., 2005).

The first issue in optimising the response surface is performance of the suggested model regression. In this regard, various statistical factors must be determined. In the present study, a determination coefficient $\mathrm{R}^{2}=0.9796$ represents a very good fit of the regression model to the data. When the $\mathrm{R}^{2}$ value is close to one, the model predicts the response better (Muhamad et al., 2013). The statistical model with the lowest difference between modified $\mathrm{R}^{2}$ and predicted $\mathrm{R}^{2}$ is the most appropriate (Liu et al., 2013). In this study, the modified $R^{2}$ was 0.9612 and $R^{2}$ predicted was 0.9521 with the difference between them being very low. Signal to noise ratio in response surface models must be greater than 4 (Ren et al., 2008). For this model, signal to noise ratio was 27.124 , which represents a desired signal and model performance. The lack of fit examines the remaining error to absolute error. Lack of fit was not significant in the model $(p>0.05)$, which indicates the model had a reasonable fit. The results of the interaction between temperature and time $(\mathrm{p}<0.0001)$ and interaction between time and enzyme to substrate ratio $(\mathrm{p}<0.0001)$ were also significant. However, the interaction between temperature and enzyme to substrate ratio was not significant $(\mathrm{p}>0.05)$. The regression equation for the coded values and the actual values are given in Equations 2 and 3 below:

Chelating activity $=+65.02+8.50 \mathrm{X}_{1}+4.90 \mathrm{X}_{2}+11.90 \mathrm{X}_{3}$ $7.05 \mathrm{X}_{1}^{2}-15.05 \mathrm{X}_{2}^{2}+4.95 \mathrm{X}_{3}^{2}+8.25 \mathrm{X}_{1} \mathrm{X}_{2}-2.50 \mathrm{X}_{1} \mathrm{X}_{3}-9.25$ $\mathrm{X}_{2} \mathrm{X}_{3}$

Chelating activity $=-132.75051+4.61455 X_{1}+0.38085$

$\mathrm{X}_{2}+11.47652 \mathrm{X}_{3}-0.045091 \mathrm{X}_{1}^{2}-1.8574 \mathrm{X}_{2}^{2}+1.23864 \mathrm{X}_{3}^{2}$ $+7.33333 \mathrm{X}_{1} \mathrm{X}_{2}-0.1 \mathrm{X}_{1} \mathrm{X}_{3}-0.051389 \mathrm{X}_{2} \mathrm{X}_{3} \cdots \cdots \cdots \cdots \cdots \cdots \cdots \ldots . . . \cdots(3)$

Normal probability distribution of data and comparison of the model predictions and actual results are shown in Figs. 1 and 2. Fig. 1 indicates the normal distribution of the experimental data. Fig. 2 indicates the good fit of the final model since the numerical predictions from the model and the experimental values fell on a straight line. This graph shows reasonable fitness of experimental point with the model's predicted value and high accuracy of the statistical model regarding the chelating activity of marine catfish skin ( $N$. thalassina) gelatin hydrolysis.

The effects of temperature (A) and time (B) are illustrated in Fig. 3. At an enzyme to substrate ratio of $3 \%$, an increase in temperature up to $52.5^{\circ} \mathrm{C}$ increased the percentage of chelating linearly, beyond that, it decreased. 
Table 3. Analysis of variance of the response surface quadratic model of sea catfish $(N$. thalassina $)$ skin gelatin

\begin{tabular}{llllll}
\hline Source & Sum of squares & Degrees of freedom & Mean square & F value & $\mathrm{p}$ (Prob $>$ F) \\
\hline Model & 5139.77 & 9 & 571.09 & 53.28 & $<0.0001$ \\
Temp $(A)$ & 722.50 & 1 & 722.50 & 67.41 & $<0.0001$ \\
Time (B) & 240.10 & 1 & 240.10 & 22.40 & 0.0008 \\
e/s $(C)$ & 1416.10 & 1 & 1416.10 & 132.12 & $<0.0001$ \\
$A B$ & 544.50 & 1 & 544.50 & 50.80 & $<0.0001$ \\
$A C$ & 50.00 & 1 & 50.00 & 4.66 & 0.0561 \\
$B C$ & 684.50 & 1 & 684.50 & 63.86 & $<0.0001$ \\
$A^{2}$ & 136.51 & 1 & 136.51 & 12.74 & 0.0051 \\
$B^{2}$ & 622.51 & 1 & 622.51 & 58.08 & $<0.0001$ \\
$C^{2}$ & 67.51 & 1 & 67.51 & 6.30 & 0.0309 \\
Residual & 107.18 & 10 & 10.72 & & 0.9927 \\
Lack of Fit & 7.85 & 5 & 1.57 & 0.079 & \\
Pure Error & 99.33 & 5 & 19.87 & & \\
Correction total & 5246.95 & 19 & & & \\
\hline
\end{tabular}

Likewise, increasing the time up to $150 \mathrm{~min}$, increased chelating activity. At a duration of more than $150 \mathrm{~min}$, the percentage of chelation reduced. Simultaneously increasing temperature and time causes increase in the percentage of metal chelation. This increase occurred at temperatures lower than $52.5^{\circ} \mathrm{C}$ at a duration more than $150 \mathrm{~min}$ whereas at higher temperatures at durations of more than 195 min chelating activity showed a decreasing trend.

Fig. 4 shows the percentage of the $\mathrm{Fe}^{2+}$ chelation as a function of temperature and enzyme to substrate ratio, where the time was constant at $150 \mathrm{~min}$, indicated that the percentage of chelation increased when enzyme to substrate ratio increased. However, this increase was not noticeable up to the $3 \%$ level of the enzyme, while there was considerable chelating activity at enzyme levels higher than $3 \%$. Increasing the percentage of enzymes along with temperatures increased the percentage of chelation through interaction effects, but this rising trend continued only up to $58.75^{\circ} \mathrm{C}$ and at temperatures above $58.75^{\circ} \mathrm{C}$, each of the enzyme's levels caused reduction in the chelation percentage.

As shown in Fig. 5, at constant temperature of $52.5^{\circ} \mathrm{C}$ and increase in time up to 150 min linearly increased the chelation percentage and beyond 150 min there was no tangible effect on the percentage of chelation. Increasing the percentage of enzyme caused linear increase in chelation. The increase of enzyme to substrate ratio along with an increase in the duration of hydrolysis up to $150 \mathrm{~min}$, resulted in increasing the percentage of chelation as interaction. At high hydrolysis temperature, increasing the enzyme to substrate ratio caused decrease in the percentage of chelation. The maximum chelating activity was $73.30 \%$ observed at enzyme level of $5 \%$ and hydrolysis time of $150 \mathrm{~min}$. Optimal conditions for the

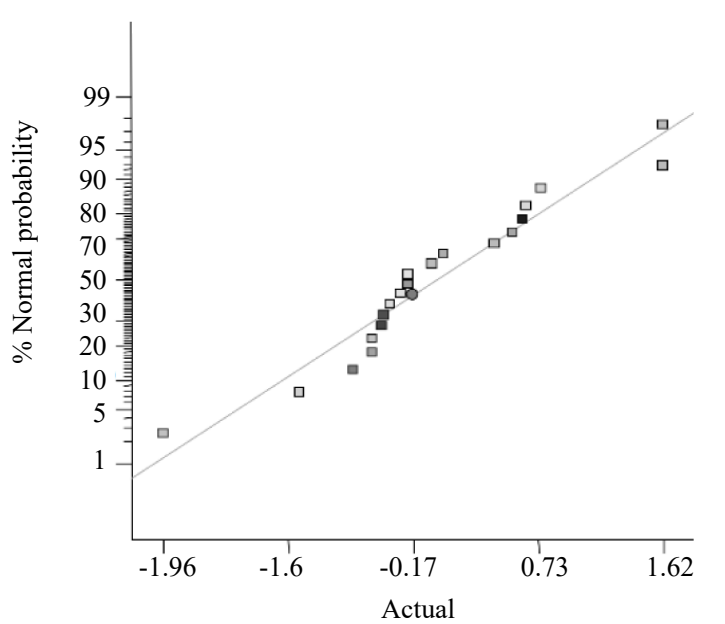

Fig 1. Normal probability distribution data of catfish skin gelatin hydrolysate

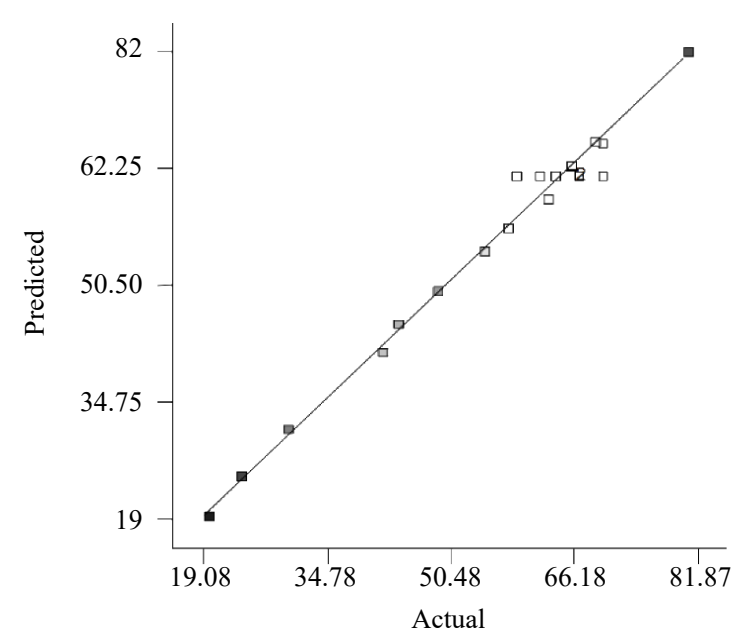

Fig 2. Comparison model predictions against experimental values of catfish skin gelatin hydrolysate 


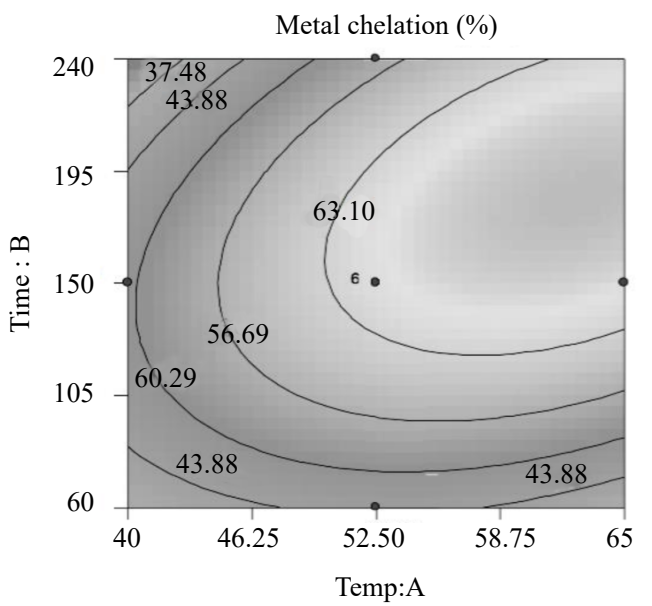

(a)

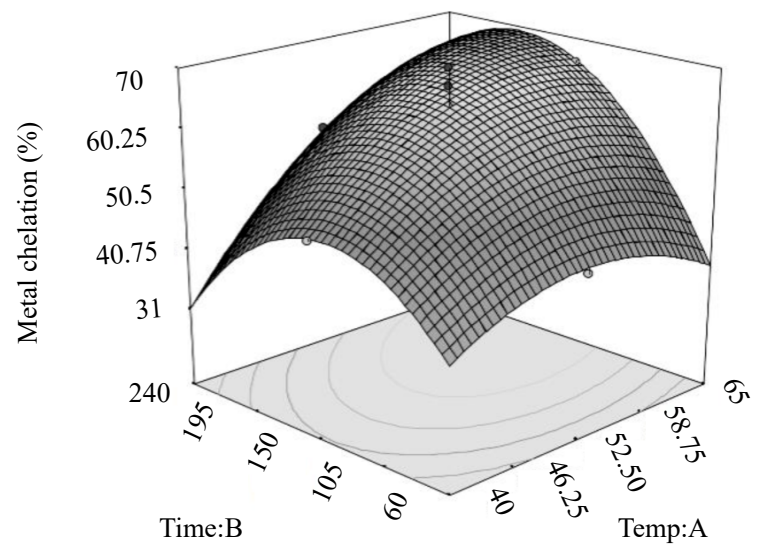

(b)

Fig. 3. Contour plot and response surface for the effect of (a) temperature A and (b) time B on the chelating activity of sea catfish (N. thalassina) skin gelatin

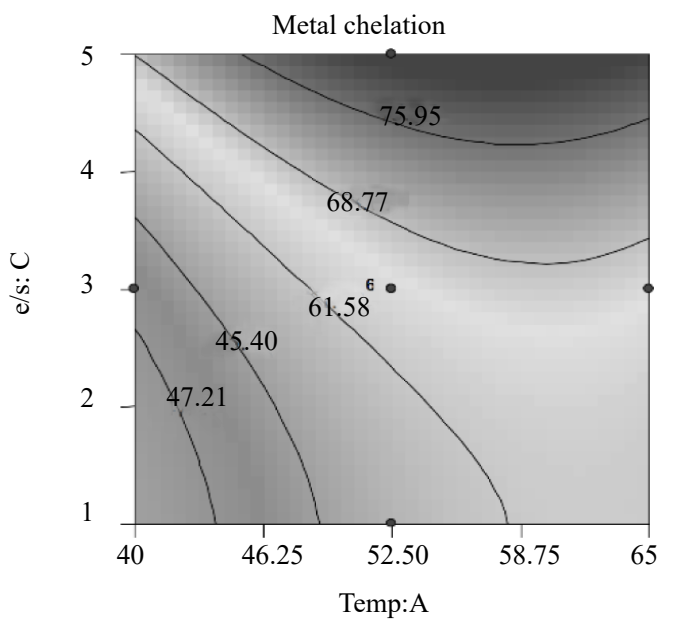

(a)

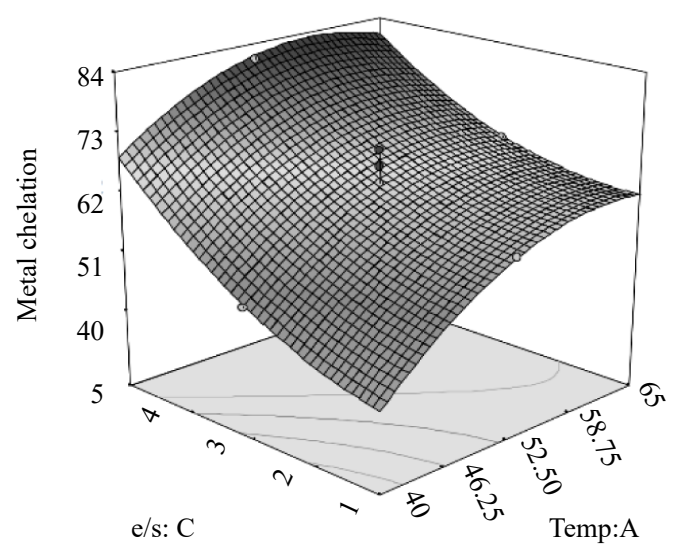

(b)

Fig. 4. Contour plot and response surface for the effect of (a) temperature A and (b) e/s C on the chelating activity of sea catfish (N. thalassina) skin gelatin

production of gelatin hydrolysate with the highest activity of $\mathrm{Fe}^{2+}$ chelation based on the confirmed model were as follows: Temperature $-56.55^{\circ} \mathrm{C}$, enzyme to substrate ratio - $4.93 \% \mathrm{t}$ and time -149.23 min with metal ion chelating activity of $82.33 \%$.

Contour plots and the response surface of the effects of temperature and time on percentage of chelation shows that by the beginning of hydrolysis process, production of peptides that had chelating activity and capable of oxidation of metal ions starts and its optimal range is at temperature of $52.5-65^{\circ} \mathrm{C}$ and time duration of 150-195 min which decreased beyond this optimal range. At the beginning of the reaction, hydrolysis releases the antioxidant peptide which increases the antioxidant activity of hydrolysate. More reactions, out of the optimal range, can cause excessive hydrolysis of antioxidant peptides, their break down to free amino acids and reduce the inhibition activity of the hydrolysate (Ren et al., 2008).

Unlike many other studies that reported increased antioxidant activity with increased hydrolysis temperature and time; in this study, very high temperature for long periods decreased antioxidant activity. This indicated the presence of an optimal temperature range for optimal performance of Protamex ${ }^{\mathrm{TM}}$ (E.C. 3.4.21.62/ 3.4.24.28) enzymes. Similar results were found in the study of Ren et al. (2008) on protein hydrolysis of grass carp, where the inhibitory activity increased from $1 \mathrm{~h}$ to about $6 \mathrm{~h}$. However, more treatment time (6 to $12 \mathrm{~h}$ ) decreased 


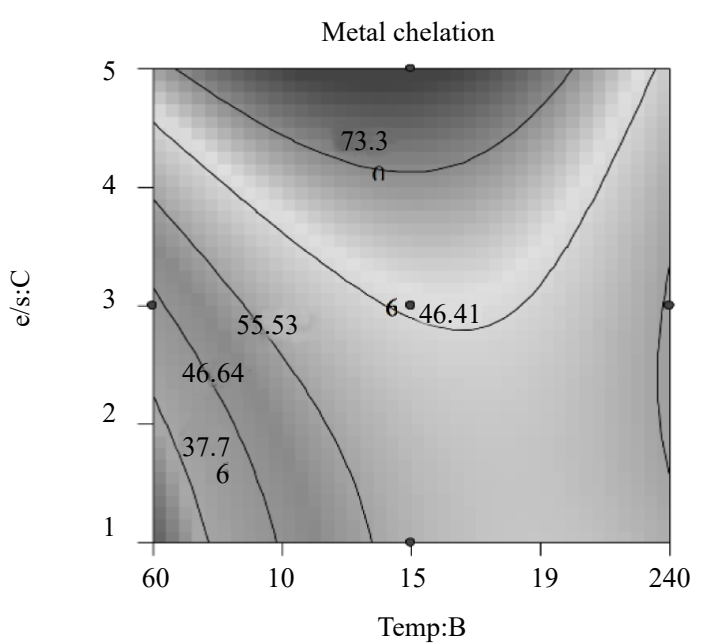

(a)

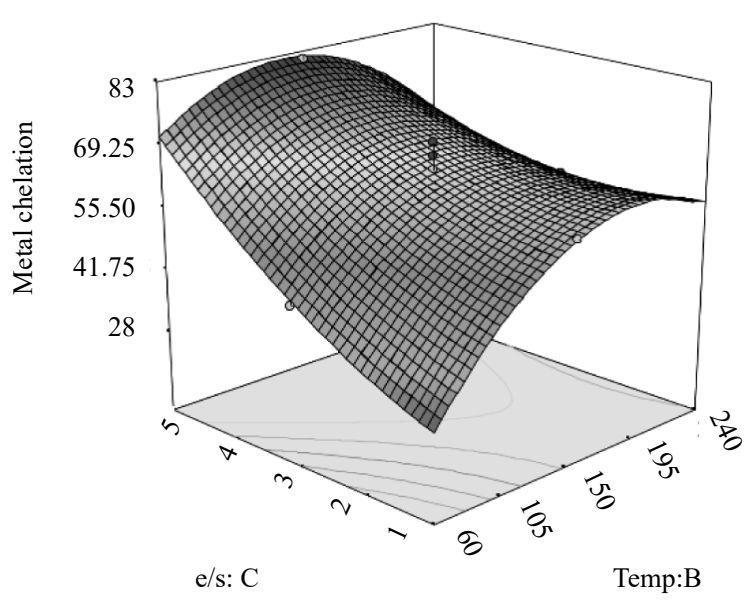

(b)

Fig. 5. Contour plot and response surface for the effect of (a) time B and (b) e/s C on the chelating activity of sea catfish (N. thalassina) skin gelatin

inhibitory activity that was not expected (Ren et al., 2008). In a study conducted by Fang et al. (2012) on squid protein hydrolysis, increase in the hydrolysis temperature and time caused increased free radical scavenging, which then reduced with further increase of temperature and time. Also, Limpisophon et al. (2020), reported that proteolytic activity of the enzyme increased at above 30 to $60^{\circ} \mathrm{C}$ and then declined beyond $65^{\circ} \mathrm{C}$ due to enzyme denaturation. Differences in optimal temperatures at different studies were probably due to different substrates and conditions used for hydrolysate production.

According to the response surface and contour plots of the effects of temperature (A) and enzyme to substrate ratio (C) on the $\mathrm{Fe}^{2+}$ chelation (Fig. 4), increasing the temperature beyond a certain level decreased the chelating activity. This issue can be due to the instability of enzyme at high temperatures and also quicker enzyme denaturation at high temperatures, which reduces its biological activity. These results showed that enzyme to substrate ratio and temperature have an optimum limit to produce peptides with antioxidant properties.

Fang et al. (2012) in their study on squid protein hydrolysis using papain enzymes reported that the temperature in the range of $45-51{ }^{\circ} \mathrm{C}$ increased the free radical scavenging activity, however, higher temperatures can reduce the inhibitory activity. In a study of Wangtueai et al. (2016), on lizardfish scale gelatin hydrolysation, when the e/s ratio was increased, the (2,2'-azino-bis (3-ethylbenzothiazoline-6-sulfonic acid (ABTS) radical scavenging increased. The optimal temperature and time of hydrolysation were between 45 to $55^{\circ} \mathrm{C}$ and 1 to $2 \mathrm{~h}$. But at this time, ferric reducing ability of plasma (FRAP) decreased and when the time reached 2 to $3 \mathrm{~h}$, it increased. The effects of temperature and e/s ratio for FRAP were the same as ABTS test.

Our results indicated that the percentage of chelation increased with increase in the enzyme to substrate ratio which may be due to more hydrolysis of gelatin when adding more protease; in this case, a high proportion of enzyme to substrate ratio is desired to enhance the chelation reaction. It is also possible that as time increases the stability of the enzyme is reduced and the reaction does not follow the laws of thermodynamics and aggregation of product reached to such an extent that have an inhibition property (Styer, 1988). This also might explain the reduction in chelation percent in the longer time duration (Fig. 5). In a study of Fang et al. (2012), 2,2-Diphenyl-1-picrylhydrazyl (DPPH) radical scavenging ability increased gradually from 45 to $51{ }^{\circ} \mathrm{C}$ while the activity reduced in the range of $51-55^{\circ} \mathrm{C}$. Similar results were reported by Ren et al. (2008) in their study on grass carp muscle sarcoplasmic protein with papain enzyme, that at constant temperature, increasing the enzyme to substrate ratio increased the inhibitory activity. Several factors, including protein extraction conditions, the degree of hydrolysis and proteolytic enzyme type, can impact the antioxidant activity of bioactive peptides (Liu and Chiang, 2008). Moreover, the e/s ratio had the most significant effect on the antioxidant properties of jellyfish collagen hydrolysate (Zhuang et al., 2009). Also, You et al. (2010), reported that DPPH free radical scavenging activity increased significantly at hydrolysis time between 1 to $2 \mathrm{~h}(\mathrm{p}<0.05)$. 
In the present study, optimum conditions of the predicted model was at a reaction temperature of $56.55^{\circ} \mathrm{C}$, an enzyme to substrate ratio of $4.93 \%$ and reaction time of 149.23 min with a $\mathrm{Fe}^{2+}$ chelation rate of $82.3349 \%$ that was very close to the experimental data. Zhuang et al. (2009), reported an optimal $\mathrm{pH}$ of 7.75 , temperature of $48.77^{\circ} \mathrm{C}$ and $\mathrm{e} / \mathrm{s}$ ratio of $3.50 \%$ for jellyfish collagen hydrolysate production. You et al. (2010), worked on fish gelatin hydrolysate preparation with antioxidant properties. They reported an e/s ratio of $3 \%$ at $52.1^{\circ} \mathrm{C}$ and $2.65 \mathrm{~h}$ as optimum conditions. The DPPH and ABTS free radical scavenging activity were $97.3 \%$ and $9.86 \mathrm{mM}$ Trolox, respectively. Moreover, the optimum conditions for lizardfish (Saurida spp.) scale gelatin hydrolysate with antioxidant activity were $3 \% \mathrm{e} / \mathrm{s}$ at $55^{\circ} \mathrm{C}$ for $3 \mathrm{~h}$, and the FRAP activity was $61.7 \%$ (Wangtueai et al., 2016). The optimum conditions for shark skin gelatin hydrolysate with antioxidant activity were $60^{\circ} \mathrm{C}, \mathrm{pH} 7.5$ and enzyme of $2.70 \mathrm{Au} \mathrm{kg}^{-1}$ (Limpisophon et al., 2020). Optimum conditions for fish gelatin hydrolysate thus depend on the kind of substrate and enzyme and for each study, the optimal conditions are different.

The molecular structure and mass of bioactive peptides obtained by the hydrolysation of gelatin are influenced by the reaction conditions. Gelatin peptides contain hydrophobic amino acids that could act as antioxidant agents. So gelatin peptides impart more antioxidant effects than other peptide sequences. Also, several studies have reported that aromatic amino acids and histidine play a critical role in these activities (Mendis et al., 2005a, b). Based on published literature, it is known that the hydrolysation process produces a mix of amino acids and peptides that have reduction power by donating the electron. Peptides by their higher electron donating ability, have better reducing power, and are excellent antioxidant agents (Pezeshk et al., 2018; Tkaczewska et al., 2020).

In the present study, catfish skin gelatin hydrolysate ( $N$. thalassina) showed a good $\mathrm{Fe}^{2+}$ chelating activity. The hydrolysation at optimum conditions of $56.55^{\circ} \mathrm{C}$, e/s ratio of $4.93 \%$ and at $149.23 \mathrm{~min}$, showed metal-chelation of $82.33 \%$. These results indicated that antioxidant peptides derived from catfish skin gelatin hydrolysate can be a potential candidate in the pharmaceutical industry and in the development of functional foods with antioxidant potential. However, additional in vivo model system studies for food and medical purposes are necessary.

\section{Acknowledgments}

Authors are grateful to the authorities for providing research facilities at the Chabahar Maritime University, Iran.

\section{References}

Aewsiri, T., Benjakul, S., Visessanguan, W., Wierenga, P. A. and Gruppen, H. 2010. Antioxidative activity and emulsifying properties of cuttlefish skin gelatin-tannic acid complex as influenced by types of interaction. Innov. Food Sci. Emerg. Technol., 11(4): 712-720.

Aleman, A., Gimenez, B., Montero, P. and Gomez-Guillen, M. C. 2011a. Antioxidant activity of several marine skin gelatins. J. Food Sci. Technol., 44(2): 407-413. DOI: 10.1016/j. lwt.2010.09.003.

Aleman, A., Perez-Santín, E., Bordenave-Juchereau, S., Arnaudin, I., Gomez-Guillen, M. C. and Montero, P. 2011 b. Squid gelatin hydrolysates with antihypertensive, anticancer and antioxidant activity. Food Res. Int., 44(4): 1044-1051. DOI: 10.1016/j.foodres.2011.03.010.

Badii, F. and Howell, N. 2006. Fish gelatin: Structure, gelling properties and interaction with egg albumen proteins. Food Hydrocoll., 20(5): 630-640. https://doi.org/10.1016/j. foodhyd.2005.06.006.

Duan, R., Zhang, J., Xing, F., Konno, K. and Xu, B. 2011. Study on the properties of gelatins from skin of carp (Cyprinus carpio) caught in winter and summer season. Food Hydrocoll., 25: 368-373. DOI: 10.1016/j. foodhyd.2010.07.002.

Fang, X., Xie, N., Chen, X., Yu, H. and Chen, J. 2012. Optimisation of antioxidant hydrolysate production from flying squid muscle protein using response surface methodology. Food Bioprod. Process., 90(4): 676-682. DOI:10.1016/j.fbp.2012.04.001.

Farvin, S. K. H., Andersen, L. L., Nielsen, H. H., Jacobsen, C., Jakobsen, G., Johansson, I. and Felleming, J. 2014. Antioxidant activity of cod (Gadus morhua) protein hydrolysates: In vitro assays and evaluation in 5\% fish oilin-water emulsion. Food Chem., 149: 326-334.

Gimenez, B., Aleman, A., Montero, P. and Gomez-Guillen, M. C. 2009. Antioxidant and functional properties of gelatin hydrolysates obtained from skin of sole and squid. Food Chem., 114(3): 976-983. https://doi.org/10.1016/j. foodchem.2008.10.050.

Gomez-Guillen, M. C., Gimenez, B., Lopez-Caballero, M. E. and Montero, M. P. 2011. Functional and bioactive properties of collagen and gelatin from alternative source: A review. Food Hydrocoll., 25(8): 1813-1827. https://doi. org/10.1016/j.foodhyd.2011.02.007.

Guerard, F., Sumaya-Martinez, M., Laroque, D., Chabeaud, A. and Dufosse, L. 2007. Optimisation of free radical scavenging activity by response surface methodology in the hydrolysis of shrimp processing discards. Process Biochem., 42(11): 1486-1491. DOI:10.1016/j.procbio. 2007.07.016.

Intarasirisawat, R., Benjakul, S., Visessanguan, W. and Wu, J. 2012. Antioxidative and functional properties of protein 
hydrolysate from defatted skipjack (Katsuwonous pelamis) roe. Food Chem., 135: 3039-3048. doi: 10.1016/j. foodchem.2012.06.076.

Karim, A. and Bhat, R. 2009. Fish gelatin: Properties, challenges and prospects as an alternative to mammalian gelatins. Food Hydrocoll., 23(3): 563-576. DOI: 10.1016/j.foodhyd. 2008.07.002.

Kim, S., Kim, Y., Byun, H., Nam, K., Joo, D. and Shahidi, F. 2001. Isolation and characterization of antioxidative peptides from gelatin hydrolysate of Alaska pollack skin. J. Agric. Food Chem., 49(4): 1984-1989. doi: 10.1021/ jf000494j.

Klompong, V., Benjakul, S., Kantachote, D. and Shahidi, F. 2007. Antioxidative activity and functional properties of protein hydrolysate of yellow stripe trevally (Selaroides leptolepis) as influenced by the degree of hydrolysis and enzyme type. Food Chem., 102(4): 1317-1327. DOI:10.1016/j. foodchem.2006.07.016.

Koli, J. M., Basu, S., Nayak, B., Patange, S., Pagarkar, A. and Gudipati, V. 2012. Functional characteristics of gelatin extracted from skin and bone of tiger-toothed croaker (Otolithes ruber) and pink perch (Nemipterus japonicus). Food Bioprod. Process., 90(3): 555-562. DOI:10.1016/j. fbp.2011.08.001.

Limpisophon, K., Shibata, J., Yasuda, Y., Tanaka, M. and Osako, K. 2020. Optimization of hydrolysis conditions for production of gelatin hydrolysates from shark skin byproduct and evaluation of their antioxidant activities. J. Aquat. Food Prod. Technol., 29(8): 739-749.

Liu, B. L. and Chiang, P. S. 2008. Production of hydrolysate with antioxidative activity and functional properties by enzymatic hydrolysis of defatted sesame (Sesamum indicum L.). J. Appl. Sci. Eng., 6(2): 73-83.

Liu, Y., Wei Shoulian and Liao, M. 2013. Optimization of ultrasonic extraction of phenolic compounds from Euryale ferox seed shells using response surface methodology. J. Ind. Crop Product., 49: 837-843. https://doi.org/10. 1016/j.indcrop.2013.07.023.

Mendis, E., Rajapakse, N. and Kim, S. 2005a. Antioxidant properties of a radicals scavenging peptide purified from enzymatically prepared fish skin gelatin hydrolysate. J. Agric. Food Chem., 53(3): 581-587. doi: 10.1021/ jf048877v.

Mendis, E., Rajapakse, N., Byun, H. G. and Kim, S. K. 2005b. Investigation of jumbo squid (Dosidicus gigas) skin gelatin peptides for their in vitro antioxidant effects. J. Life Sci., 77(17): 2166-2178. doi: 10.1016/j.lfs.2005.03.016.

Muhamad, M. H., Sheikh Abdullah, S. A., Mohamad, A. B., Abdul Rahman, R., Kadhum, H. and Amir, A. 2013. Application of response surface methodology (RSM) for optimization of $\mathrm{COD}, \mathrm{NH}_{3}-\mathrm{N}$ and 2,4-DCP removal from recycled paper wastewater in a pilot-scale granular activated carbon sequencing batch biofilm reactor (GACSBBR). J. Enviro.. Manage., 121: 179-190. DOI:10.1016/j. jenvman.2013.02.016.
Najafian, L. and Babji, A. 2012. A review of fish-derived antioxidant and antimicrobial peptides: Their production, assessment and applications. Peptides, 33(1): 178-185. doi: 10.1016/j.peptides.2011.11.013.

Ngo, D. H., Ryu, B., Vo, T. S., Himaya, S. W., Wijesekara, I. and Kim, S. K. 2011. Free radical scavenging and angiotensin-I converting enzyme inhibitory peptides from Pacific cod (Gadus macrocephalus) skin gelatin. J. Biol. Macromol., 49(5): 1110-1116. DOI: 10.1016/j.ijbiomac.2011.09.009.

Pezeshk, S., Ojagh, S. M., Rezaei, M. and Shabanpour, B. 2018. Fractionation of protein hydrolysates of fish waste using membrane ultrafiltration: Investigation of antibacterial and antioxidant activities. Probiot. Antimicrob. Proteins, 11(3): 1015-1022.

Phanturat, P., Benjakul, S., Visessanguan, W. and Roytrakul, S. 2010. Use of pyloric caeca extract from bigeye snapper (Priacanthus macracanthus) for the production of gelatin hydrolysate with antioxidative activity. J. Food Sci. Technol., 43: 86-97. DOI:10.1016/j.lwt.2009.06.010.

Rajapakse, N., Mendis, E., Jung, W. K., Je, J. Y. and Kim, S. K. 2005. Purification of a radical scavenging peptide from fermented mussel sauce and its antioxidant properties. J. Food Res. Int., 38(2): 175-182. https://doi.org/10.1016/j. foodres.2004.10.002.

Ren, J., Zhao, M., Shi, J., Wang, J., Jiang, Y., Cui, C., Kakuda, Y. and Xue, J. 2008. Optimization of antioxidant peptide production from grass carp sarcoplasmic protein using response surface methodology. J. Food Sci. Technol., 41(9): 1624-1632.

Sarmadi, B. H. and Ismail, A. 2010. Antioxidative peptides from food proteins: A review. Peptides, 31(10): 1949-1956. doi: 10.1016/j.peptides.2010.06.020.

Tkaczewska, J., Borawska-Dziadkiewicz, J., Kulawik, P., Duda, I., Morawska, M. and Mickowska, B. 2020. The effects of hydrolysis condition on the antioxidant activity of protein hydrolysate from Cyprinus carpio skin gelatin. LWT - Food Sci. Technol., 117: 108616.

Wangtueai, S., Siebenhandl-Ehn, S. and Haltrich, D. 2016. Optimisation of the preparation of gelatin hydrolysates with antioxidative activity from lizardfish (Saurida spp.) scales gelatin. Chiang Mai J. Sci., 43(1): 68-79.

Yang, J. L., Liang, W. S., Chow, C. J. and Siebert, K. J. 2009. Process for the production of tilapia retorted skin gelatin hydrolysates with optimised antioxidative properties. Process Biochem., 44(10): 1152-1157.

You, L., Regenstein, J. M. and Liu, R. H. 2010. Optimisation of hydrolysis conditions for the production of antioxidant peptides from fish gelatin using response surface methodology. J. Food Sci., 75(6): 582-587.

Zhang, Y., Duan, X. and Zhuang, Y. 2012. Purification and characterisation of novel antioxidant peptides from 
enzymatic hydrolysates of tilapia (Oreochromis niloticus) skin gelatin. Peptides, 38(1): 13-21. doi: 10.1016/j. peptides.2012.08.014.

Zhou, D. Y., Tanga, Y., Zhu, B. W., Qin, L., Li, D. M., Yang, J. F., Lei, K. and Murata, Y. 2012. Antioxidant activity of hydrolysates obtained from scallop
(Patinopecten yessoensis) and abalone (Haliotis discus hannai Ino) muscle. Food Chem., 132(2): 815-822.

Zhuang, Y. L., Zhao, X. and Li, B. F. 2009. Optimization of antioxidant activity by response surface methodology in hydrolysates of jellyfish (Rhopilema esculentum) umbrella collagen. J. Zhejiang Uni. Sci. B, 10(8): 572-579. 